\title{
Autoantibodies to the HLA-B27 Sequence Cross-react with the Hypothetical Peptide from the Arthritis-associated Shigella Plasmid
}

\author{
Naoyuki Tsuchiya, ${ }^{\star}$ Gunnar Husby, ${ }^{\star}$ Ralph C. Williams, Jr., ${ }^{*}$ Heather Stieglitz, ${ }^{\ddagger}$ Peter E. Lipsky, ${ }^{\ddagger}$ and Robert D. Inman \\ ${ }^{*}$ Division of Rheumatology and Clinical Immunology, Department of Medicine, University of Florida, Gainesville, Florida 32610; \\ ${ }^{\ddagger}$ Department of Internal Medicine and the Harold C. Simmons Arthritis Research Center, University of Texas Southwestern Medical \\ Center, Dallas, Texas 75235; and ${ }^{\S}$ Rheumatic Disease Unit, Toronto Western Hospital, Toronto, Ontario, Canada M5T $2 S 8$
}

\begin{abstract}
We previously reported elevated serum antibody levels to a peptide representing the HLA-B27 polymorphic region (B27 peptide) in HLA-B27(+) ankylosing spondylitis (AS) patients. A plasmid (pHS-2) isolated from arthritogenic Shigella flexneri strains had been shown to encode an amino acid sequence homologous to HLA-B27. Rabbit antibody to this sequence (pHS-2 peptide) strongly cross-reacted with B27 peptide and, to a much lesser extent, with Klebsiella nitrogenase peptide. Serum antibody levels to pHS-2 peptide were studied in 160 spondylarthropathy patients. 12 of $115(10.4 \%)$ AS patients, 2 of $45(4.4 \%)$ patients with Reiter's syndrome or reactive arthritis, as well as 6 of $147(4.1 \%)$ normal controls were shown to have elevated anti-pHS-2 peptide antibodies. Antibody levels to $\mathrm{B} 27$ and pHS-2 peptides were significantly correlated in 134 HLA-B27 $(+)$ patients $(r=0.333, P<0.001) .13$ of 15 affinity-purified anti-B27 peptide antibodies from patients strongly cross-reacted with pHS-2 peptide, whereas only 3 weakly cross-reacted to nitrogenase peptide. Leucine appeared to be a critical residue for this cross-reaction. AS patients' anti-B27 peptide antibodies reacted with HLA-B27 transfected L cells. These results may suggest that pHS-2 peptide more efficiently "mimics" B27 peptide than does nitrogenase peptide. Involvement of pHS-2 in pathogenesis of spondylarthropathy through molecular mimicry mechanisms requires further study. ( $J$. Clin. Invest. 1990. 86:1193-1203.) Key words: HLA-B27 antigen • molecular mimicry $\cdot$ Shigella plasmid
\end{abstract}

\section{Introduction}

Although several hypotheses have been proposed, the actual mechanism for development of the seronegative spondylarthropathies and their relationship to HLA-B27 antigen still remain unclear (1). Recent advances in molecular biology and peptide synthesis technology have provided considerable new information concerning the theory of molecular mimicry (2-8). Thus, Schwimmbeck and associates (9) found a homologous six-amino acid sequence between the polymorphic re-

\footnotetext{
Address reprint requests to Dr. Williams, Box J-221, JHMHC, University of Florida, Gainesville, FL 32610.

Received for publication 11 May 1989 and in revised form 24 April 1990.
}

J. Clin. Invest.

(c) The American Society for Clinical Investigation, Inc.

$0021-9738 / 90 / 11 / 1193 / 11 \quad \$ 2.00$

Volume 86, October 1990, 1193-1203 gion of $\mathrm{B}^{*} 2705$ antigen ${ }^{1}$ and Klebsiella pneumoniae nitrogenase $^{2}$ (Table I). They also detected elevated levels of serum antibodies against synthetic peptides encompassing the homologous sequence in a significant proportion of patients with ankylosing spondylitis (AS) ${ }^{3}$ or Reiter's syndrome (RS).

We previously demonstrated that this shared epitope is strongly expressed in the synovial tissue of patients with AS and HLA-B27 (14). We also confirmed the elevated level of serum antibodies to the peptide representing the HLA-B27 polymorphic region (B27 peptide) in some patients with AS, however, these human antibodies did not seem to cross-react with the peptide representing Klebsiella pneumoniae nitrogenase (nitrogenase peptide) (15).

Recently, a 2-MD plasmid, pHS-2, was identified in four arthritogenic Shigella flexneri strains (13). DNA sequence analysis revealed that one of the possible open reading frames encoded a 22-amino acid peptide which has a sequence homologous to the same polymorphic region of HLA-B27 (Table I). Initial Western blotting studies appeared to indicate that this putative gene product was expressed in the arthritogenic strains (16), however, subsequent attempts to define bacterial expression have not as yet yielded positive results. It is clear that the plasmid pHS-2 sequence codes for a homologous peptide but whether this product is transiently or uniformly expressed in infected patients is not clear. We have examined the presence of antibodies against a peptide representing the homologous region of pHS- 2 (pHS- 2 peptide), as well as the potential cross-reactivity of anti-B27 peptide antibodies with pHS-2 peptide, in a large number of patients with AS, RS, or reactive arthritis. Attempts have also been made to examine whether the anti-B27 peptide antibody would bind to the native B27 molecule. In addition, a series of synthetic peptides were used to attempt to establish critical residues for the crossreactivity.

\section{Methods}

Patients and controls. 115 patients with AS, 45 patients with RS or reactive arthritis, as well as 147 normal controls were studied. Patient

1. A new WHO designation has recently been adopted (10), which has changed the nomenclature for HLA-B27 subtypes. The amino acid sequence of the old designation B27.1 which was used in previous reports, should now be referred to as $B^{*} 2705$.

2. The nitrogenase enzyme complex consists of two components. The homologous sequence studied in this paper occurs in component 2 , or nitrogenase reductase (11). For simplicity, the peptide representing this sequence is referred as "nitrogenase peptide" in this study.

3. Abbreviations used in this paper: AS, ankylosing spondylitis; CELISA, cell ELISA; RS, Reiter's syndrome. 
Table I. Amino Acid Sequences of HLA-B27 Antigens, Klebsiella pneumoniae Nitrogenase, and pHS-2

\begin{tabular}{|c|c|c|}
\hline A. Original sequences & Residues & Amino acid sequences \\
\hline pHS-2 & & G T V C $\underline{A Q T D R}$ H S L S C I A M Q \\
\hline K. pneumoniae nitrogenase & $183-200$ & I C NSRQTDREDE L I I A L A \\
\hline HLA-B*2705 & $67-84$ & CKAKAQTDREDLRT L LRY \\
\hline B*2701 & $67-84$ & CKAKAQTYRENLRTALRY \\
\hline $\mathrm{B}^{*} 2702$ & $67-84$ & CKAKAQTDRENLRIALRY \\
\hline$B * 2704$ & $67-84$ & C KAKA QT DRES LRTLLRY \\
\hline B. Synthetic peptides used in this study & & Amino acid sequences \\
\hline B27 peptide & & AKAQT DREDLRTLLRY \\
\hline Nitrogenase peptide & & C N S R QT DREDEL I \\
\hline pHS-2 peptide & & C A Q T D RHS LSY \\
\hline \multicolumn{3}{|l|}{ pHS- 2 analogues } \\
\hline R2L9 & & $-\mathrm{R}--------$ \\
\hline A2E9 & & $-------E--$ \\
\hline R2E9 & & $-\mathrm{R}------\mathrm{E}--$ \\
\hline P-97 peptide (control) & & G MEVRWCATS DGEG \\
\hline
\end{tabular}

Amino acid sequences are shown in single-letter code. The sequences of pHS- 2 and $K$. nitrogenase homologous at $\mathrm{B}^{*} 2705$ are underlined. HLA-B27 subtypes are designated according to the new WHO nomenclature (10), and the sequences are based on references 11-13.

and control sera were collected at the Rheumatology Department, University of Tromso (Norway), University of New Mexico (USA), and Toronto Western Hospital (Canada) (Table II). An additional serum from the original reactive arthritis patient, from whom pHS-2 positive $S$. flexneri was isolated, was collected at Southwestern Medical Center in Dallas, TX. All patients and controls had been HLA-typed. The controls consisted of healthy medical staff, hospital, and laboratory personnel. The age distribution of controls and patients from Norway was 39.8 $\pm 11.1(21-62 \mathrm{yr})$ and $38.3 \pm 11.4(20-69 \mathrm{yr})$, respectively, and that from the USA was $40.2 \pm 12(25-66 \mathrm{yr})$ and $42.4 \pm 13.6$ (16-76 yr). The age distribution of Canadian patients was $28.9 \pm 8.2$ (16-52 yr), which was matched with that of Canadian controls.

Initial findings in the patients from Norway or USA have been summarized in a previous report (15). All patients with AS fulfilled the New York criteria (17) for a definite diagnosis. RS was defined as a seronegative peripheral arthritis in combination with at least one of the following characteristics: mucocutaneous lesions, inflammatory eye disease, or urethritis. Reactive arthritis was a seronegative peripheral arthritis in the absence of extra-articular features, which followed an antecedent gastrointestinal or genitourinary tract infection (18). Among the 45 patients with RS or reactive arthritis, 5 were post-Chlamydia, 6 were post-Salmonella, 4 were post-Campylobacter, and 4 were post-Shigella reactive arthritis. In the other 26 patients, causative microorganisms were not identified. Canadian samples from RS or reactive arthritis patients were collected when the articular symptoms were active. Also, about half of AS or RS patients from Norway or the USA were clinically active, as determined by concurrent clinical assessment and serum C-reactive protein determination (15).

Synthetic peptides. All peptides used in this study were prepared as originally described by Merrifield (19) (Table I), and were analyzed for purity by high-performance liquid chromatography. The peptides used were AKAQTDREDLRTLLRY residues 69-84 of HLA-B*2705 (B27 peptide), CNSRQTDREDELI residues 184-196 of Klebsiella pneumoniae nitrogenase (nitrogenase peptide), and CAQTDRHSLSY of pHS-2 (pHS-2 peptide). The carboxyl-terminal tyrosine (Y) of pHS-2 peptide (introduced to allow radioiodination) was not found in the original sequence. Three peptides with single or double amino acid substitutions from the original pHS-2 peptide, namely, CRQTDRHSLSY (R2L9), CAQTDRHSESY (A2E9), and CRQTDRHSESY (R2E9) were also synthesized. These specific substitutions were employed to attempt to define amino acid residues most likely to be involved in cross-reacting determinants. A 14-mer peptide derived from human melanoma antigen P-97, GMEVRWCATSDGEG (P-97 peptide) kindly provided by Dr. A. Latif Kazim, Department of Cell Biology, University of New Mexico, was used as a control.

An antiserum was raised in the rabbit against pHS-2 peptide crosslinked to keyhole limpet hemocyanin, and subsequently antibodies were affinity-purified using the same peptide directly coupled to agarose.

Enzyme-linked immunosorbent assay (ELISA). Serum antibody levels against synthetic peptides were assayed by ELISA as previously described (15). Briefly, duplicate wells of microtiter plates (Dynatech Laboratories, Inc., Chantilly, VA) were coated with $0.1 \mathrm{ml}$ of peptide solution $(10 \mu \mathrm{g} / \mathrm{ml})$ in carbonate buffer $\left(0.05 \mathrm{M} \mathrm{Na}_{2} \mathrm{CO}_{3}, 0.05 \mathrm{M}\right.$

Table II. Characteristics of the Patients and Normal Controls Studied

\begin{tabular}{lcccccc}
\hline & & & & \multicolumn{3}{c}{ Number studied } \\
\cline { 5 - 7 } \multicolumn{1}{c}{ Patients } & Total & HLA & Sex & Norway & USA & Canada \\
\hline Ankylosing spondylitis & 115 & B27+ & M & 50 & 26 & 9 \\
& & & F & 13 & 2 & 0 \\
& & B27- & M & 10 & 0 & 2 \\
& & & F & 3 & 0 & 0 \\
Reiter's syndrome or & & & & & & \\
reactive arthritis & 45 & B27+ & M & 6 & 7 & 12 \\
& & & F & 2 & 4 & 3 \\
& & B27- & M & 4 & 2 & 2 \\
Normal controls & 147 & B27+ & M & 11 & 6 & 2 \\
& & & F & 4 & 9 & 1 \\
& & B27- & M & 14 & 32 & 20 \\
& & & F & 30 & 17 & 1
\end{tabular}


$\mathrm{NaHCO}_{3}, \mathrm{pH}$ 9.6) $(14,15)$. Duplicate control wells received carbonate buffer alone. After overnight incubation, wells were washed three times with phosphate-buffered saline (PBS), containing $1 \%$ heat-inactivated horse serum (Sigma Chemical Co., St. Louis, MO) and $0.1 \%$ Tween 20 , and the remaining protein binding sites were saturated with dilution buffer (PBS containing 5\% heat-inactivated horse serum and $0.1 \%$ Tween 20). After washing, $0.1 \mathrm{ml}$ of serum, diluted 1:50 in dilution buffer, was added to peptide-coated or uncoated wells. After incubation for $1.5 \mathrm{~h}$, wells were washed five times with washing buffer, and $0.1 \mathrm{ml}$ of peroxidase-conjugated goat anti-human IgG + IgA + IgM (American Qualex, Inc., La Mirada, CA), diluted 10,000-fold in dilution buffer, was added. After incubation for $1.5 \mathrm{~h}$, wells were washed six times with washing buffer. $0.1 \mathrm{ml}$ of enzyme substrate solution, consisting of phosphate-citrate buffer with $0.4 \mathrm{mg} / \mathrm{ml} o$-phenylenediamine (Sigma Chemical Co.) and $0.01 \% \mathrm{H}_{2} \mathrm{O}_{2}$, were added for $30 \mathrm{~min}$. The reaction was stopped by $2.5 \mathrm{M} \mathrm{H}_{2} \mathrm{SO}_{4}$ and the absorbance was read at $490 \mathrm{~nm}$. Absorbance for each sample in the peptide-coated wells was corrected for nonspecific binding by subtracting the absorbance in the corresponding peptide-uncoated wells. To ensure consistency between assays, five sera including those with negative, moderate, and strong reactivity were used as reference controls in each microtiter plate, and the arbitrary ELISA unit was calculated for each sample using an intraassay standardization of each series of tests. Interassay variability was examined by using five reference sera in 14 assays. Standard deviation for each serum was $1.2,1.4,1.4,1.8$, and $2.0 \mathrm{U}$, respectively.

The same procedure was used for the assay of class-specific serum antibodies using peroxidase-conjugated affinity-purified goat antihuman IgG, anti-human IgA, or anti-human IgM (Tago, Inc., Burlingame, $\mathrm{CA}$ ).

The reactivity of affinity-purified rabbit anti-pHS-2 peptide and control rabbit IgG (Jackson Immuno Research, West Grove, PA) was examined similarly, using $1 \%$ bovine serum albumin (BSA, Sigma Chemical Co.) instead of horse serum and peroxidase-conjugated goat anti-rabbit IgG (Tago, Inc.) as a developing antibody.

Affinity-purification of human anti-B27 peptide antibodies Human anti-B27 peptide antibodies were affinity-purified from 17 sera which were found to contain elevated levels of antibodies. B27 peptide, representing HLA-B*2705 sequence, was directly coupled to cyanogen bromide-activated Sepharose 4B (Pharmacia, Uppsala Sweden) (coupling efficiency $>95 \%$ ). $0.3-1.5 \mathrm{ml}$ of serum was diluted 1:3 in PBS and applied to the B27 peptide-Sepharose 4B column. After the column was washed, bound antibodies were eluted with $0.1 \mathrm{M}$ glycine- $\mathrm{HCl}(\mathrm{pH} 2.5)$ and neutralized immediately with $1 \mathrm{M}$ Tris-HC (pH 8.5). After dialysis against PBS, eluted antibody solutions were concentrated to $1.5 \mathrm{ml}$ using YM-10 membrane (Diaflo, Amicon Corp., Danvers, MA), and their immunoglobulin concentrations measured by ELISA. These human anti-B27 peptide antibodies were assayed for their reactivity with a panel of peptides by ELISA as described above, using PBS containing $1 \%$ BSA and $0.1 \%$ Tween 20 as washing and dilution buffer. In order to detect all possible cross-reactivity, the maximum concentration available for each antibody solution was used. Peroxidase-labeled goat anti-human IgG + IgA + IgM was used as the developing antibody. In some experiments, the peptide coating solution was completely air-dried in the wells to make sure that the same quantity of each peptide remained coated on the microtiter plate.

The results were expressed as the percentage of specific binding to B27 peptide, i.e.: $100 \times(\mathrm{OD}$ of $\mathrm{Ag}$ peptide-coated wells - $\mathrm{OD}$ of uncoated wells)/(OD of B27 peptide-coated wells - OD of uncoated wells) $=\%$.

Transfected mouse L cell lines. Transfected mouse $L$ cell lines were generously provided by Dr. Joel D. Taurog, University of Texas Southwestern Medical Center at Dallas (20). One cell line was doubly transfected with the HLA-B*2705 gene and the human $\beta_{2}$-microglobulin gene, the other was transfected only with the $\beta_{2}$-microglobulin gene.

Cell ELISA (CELISA). CELISA was performed according to Baumgarten (21) with some modifications. Transfected $L$ cells were washed and resuspended in PBS at $1 \times 10^{6}$ cells $/ \mathrm{ml} .50 \mu 1$ of the cell suspension was delivered to each well of flat-bottomed microtiter plates (Dynatech Laboratories, Inc.) and the plates were centrifuged at $1,200 \mathrm{rpm}$ for $5 \mathrm{~min} .30 \mu \mathrm{l}$ of the supernatant was carefully removed by micropipette, and the plates were air-dried. After $200 \mu \mathrm{l}$ of methanol (100\%) was added to each well, the plates were centrifuged for $10 \mathrm{~min}$ at $1500 \mathrm{rpm}$. After washing with PBS, nonspecific binding sites were blocked by adding $200 \mu \mathrm{l}$ PBS containing $1 \%$ BSA and $0.02 \%$ sodium azide. After incubation overnight at $4^{\circ} \mathrm{C}$, the plates were washed, and $70 \mu$ of antibody solution in PBS containing $1 \%$ BSA was added to each well. After incubation for $2 \mathrm{~h}$, plates were washed four times, $75 \mu \mathrm{l}$ of peroxidase-conjugated $\mathrm{F}\left(\mathrm{ab}^{\prime}\right)_{2}$ fragment of goat anti-human IgG (Tago, Inc.), anti-human IgM (Jackson Immuno Research) or goat anti-mouse IgG ( $\mathrm{Fc}$ fragment specific, Accurate Chemical \& Scientific Corp., Westbury, NY), 1:10,000 dilution, was added to each well. After incubation for $1.5 \mathrm{~h}$ the plates were washed five times, and the color was developed as described in the ELISA protocol. Murine MAb ME1, an IgG1 that reacts with HLA-B27, B7, Bw22, and Bw42 (20), was kindly provided by Dr. J. D. Taurog and used as a positive control. MOPC 31C (Sigma Chemical Co.), an IgG1 MAb without known specificity, was used as a negative control.

As a control for human IgG and IgM, IgG from Cohn fraction II (Sigma Chemical Co.) isolated using DEAE Sephacel (Pharmacia) or polyclonal human IgM (Calbiochem-Behring Corp., La Jolla, CA) were used respectively.

The protein quantity of the wells after multiple washing procedures was estimated by dye-binding assay (21). Plates were coated and treated identically as described above without adding BSA or antibodies in the buffer. The plates were then washed four times with methanol and air-dried, and $30 \mu \mathrm{l}$ of protein assay solution (Bio-Rad Laboratories, Richmond, CA) was added. The plates were shaken for $5 \mathrm{~min}$, water $(120 \mu \mathrm{l})$ was added, and the plates were shaken again. The optical density was read at $630 \mathrm{~nm}$ with reference at $490 \mathrm{~nm}$.

Reactivity of anti-pHS-2 antibody with Shigella strains. In order to ascertain whether the pHS-2 peptide encompassing the HLA-B27 cross-reactive sequence was actually expressed in Shigella bacterial strains which possessed the original plasmid and which had actually been isolated from B27-positive patients with documented post-Shigella reactive arthritis, a series of studies were undertaken. Direct reactivity between rabbit affinity-purified anti-pHS-2 peptide antibody and various Shigella strains was examined both by ELISA and immunoprecipitation techniques. A series of four pHS-2 plasmid-positive Shigella strains which had been isolated from reactive arthritis patients (6115, EDL, CDI, and 6335) in parallel with several pHS-2 plasmidnegative strains not known to be associated with arthritis (7061 and C1250) were grown up in quantity, heat killed, and used either as whole bacterial suspensions or to prepare membrane and cytosol enriched fractions for ELISA testing. When whole bacteria were directly coated on ELISA plates, bacterial suspensions were adjusted to equal optical density on the spectrophotometer, applied in pH 9.6 carbonate buffer and allowed to fix to ELISA polyvinyl chloride microtiter plates (Dynatech Laboratories, Inc.) overnight at room temperature. Isolation of outer bacterial membranes employed lysis by sonication, followed by removal of unbroken cells by centrifugation for $1 \mathrm{~min}$ at $15,600 \mathrm{~g}$ in a microfuge (22). The supernatant fluid was sedimented for $30 \mathrm{~min}$ in a microfuge at $4^{\circ} \mathrm{C}$ to concentrate membranes and the pellet was resuspended in $300 \mu \mathrm{l}$ of $10 \mathrm{mM}$ Tris, $\mathrm{pH} \mathrm{8.0,}$ $5 \mathrm{mM} \mathrm{MgCl} 2-2 \%$ Triton $X-100$. The supernatant was used as presumed residual cytosol components.

Rabbit antibody produced against pHS-2 peptide CAQTDRHSLSY was isolated by adsorption to and elution from an epoxy-activated Sepharose 4B affinity column linked to the pHS-2 peptide. The affinity-isolated antibody was studied in parallel with normal rabbit IgG in ELISA assays. In several experiments, affinity-purified rabbit antipHS- 2 antibody and normal rabbit IgG were pepsin digested to produce $F\left(a b^{\prime}\right)_{2}$ fragments used in the comparative ELISA assays. This was done to rule out nonspecific binding of rabbit Ig fractions to bacteria through any $\mathrm{Fc}$ receptor mechanism.

After blocking with $1 \%$ BSA, incremental concentration of affin- 
ity-purified anti-pHS-2 peptide antibody was applied to duplicate wells and incubated for $3 \mathrm{~h}$. After washing, bound 'antibodies were developed by addition of peroxidase-labeled anti-rabbit Fc of IgG at 1:5,000 dilution.

Immunoprecipitation assays utilized $\left[\mathrm{S}^{35}\right]$ methionine and $\left[\mathrm{S}^{35}\right]-$ cysteine labeling of Shigella strains followed by addition of affinity-purified anti-pHS-2 peptide antibody, precipitation with protein $\mathrm{A}$, and subsequent SDS PAGE separation followed by autoradiography.

The possibility that molecular mimicry between the Shigella strains and HLA-B27 could be more directly related to other crossreactive epitopes aside from those ascribed to the pHS-2 plasmid was also studied. Affinity-purified human antibodies in concentration ranging from $10 \mathrm{ng}$ to $5 \mu \mathrm{g} / \mathrm{ml}$ isolated from HLA-B27 peptide affinity columns (see Table IV) were applied to microtiter plates coated with Shigella organisms including pHS-2 plasmid-positive strains isolated from patients with reactive arthritis as well as other plasmid-negative strains not known to be arthritis related. After blocking with $1 \%$ BSA, ELISA reactivity was developed by addition of peroxidase conjugated goat anti-human IgG, IgA, and IgM. Similar experiments were also done and developed with peroxidase-labeled anti-IgM alone since most human cross-reactivity occurred in IgM.

Statistical analysis. The significance of correlation was determined by linear regression analysis. Student's $t$ test was used to compare the mean results among different groups.

\section{Results}

Cross-reactivity of rabbit anti-pHS-2 peptide antibody to B27 peptide. Reactions of the affinity-purified rabbit anti-pHS-2 peptide antibody with the four peptides are shown in Fig. 1. Strong reactivity with pHS-2 peptide was present. In addition, clear cross-reactivity with B27 peptide, 1/16 as strong as with pHS-2 peptide, was observed. Weak cross-reactivity was also observed with nitrogenase peptide (1/1024 as strong as with pHS-2 peptide). Control P-97 peptide showed no significant

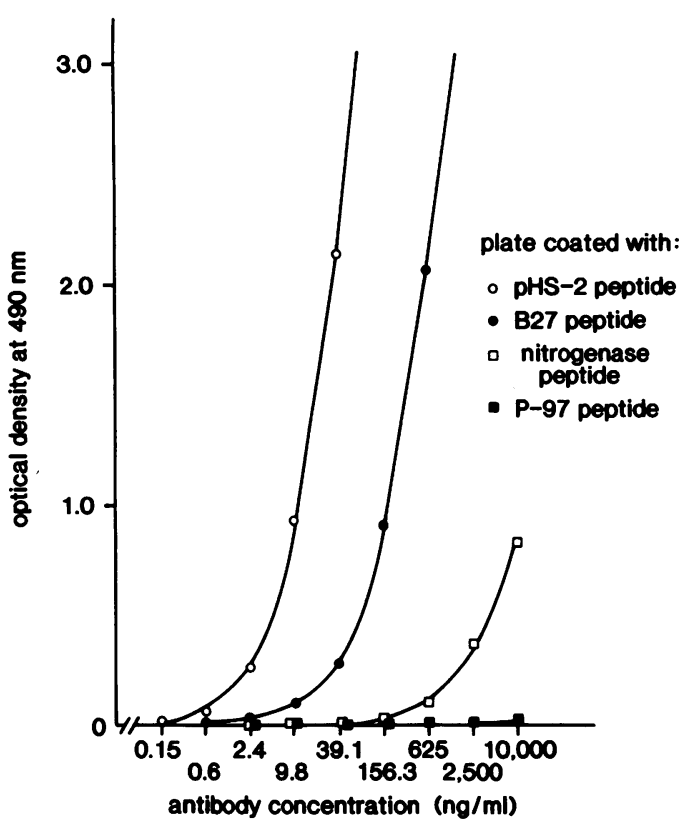

Figure 1. Results of ELISA showing reactivity of affinity-purified rabbit anti-pHS-2 peptide antibody to pHS-2 peptide (O), B27 pep-

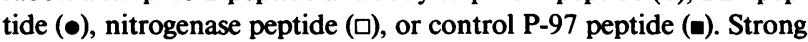
cross-reaction with B27 peptide as well as weak cross-reaction with nitrogenase peptide are shown. binding; control rabbit IgG tested at the same range of concentrations was negative for all peptides tested (data not shown).

Detection of serum anti-peptide antibodies. The patients and controls from Norway and USA, previously studied for antibody to nitrogenase and B27 peptide (15), were examined for the presence of serum antibodies to pHS- 2 peptide. Fig. 2 demonstrates IgG + IgA + IgM antibody levels of Norwegian and American subjects. The cutoff value was set at normal mean plus $2 \mathrm{SD}$ of the sex-matched controls of the respective Norwegian or American group. Unlike anti-B27 peptide antibody levels (15), differences related to previous pregnancy were not observed in female individuals. In Norwegian subjects, 7 of $60(11.7 \%)$ male AS patients, 3 of $16(18.8 \%)$ female AS patients, as well as 2 of $25(8 \%)$ normal male controls and 1 of $34(2.9 \%)$ normal female controls were positive. Among American subjects, 2 of $26(7.7 \%)$ male AS patients as well as 1 of $38(2.6 \%)$ normal male controls and 1 of $26(3.8 \%)$ normal female controls were positive. Although statistically not significant, the proportion of antibody-positive individuals and the antibody levels of the positive sera were higher in AS patients than normal controls.

Because the number of RS or reactive arthritis patients was rather small in both groups, 20 additional patients with RS or reactive arthritis and 11 patients with AS as well as 24 normal controls collected in Toronto were also studied in parallel for the presence of antibodies to B27 peptide, nitrogenase peptide and pHS-2 peptide. Since the numbers of female patients and controls were small (six and two, respectively), statistical analysis focussed principally on male subjects. The results of IgG + IgA + IgM antibodies are presented in Fig. 3. 2 out of 11 (18.2\%) Canadian AS patients and 2 out of $14(14.3 \%)$ male patients with RS or reactive arthritis were positive for antiB27 peptide antibodies, whereas none of the 22 male controls was positive. Two values, one in AS and one post-Chlamydia reactive arthritis, were extremely elevated. All four patients with elevated anti-B27 antibody levels were HLA-B27(+), while two normal male HLA-B27 $(+)$ controls from this Canadian population showed negative reactions. When antibody levels to pHS-2 peptide were compared, 2 of 14 (14.3\%) patients with RS or reactive arthritis as well as 1 of $22(4.5 \%)$ normal male controls were positive. Both of the anti-pHS-2 positive patients were also positive for the anti-B27 peptide antibodies. On the other hand, 3 of $22(13.6 \%)$ normal Canadian male controls as well as only 1 of $11(9.1 \%)$ AS patients and 2 of $14(14.3 \%)$ Canadian patients with RS or reactive arthritis were positive for the anti-nitrogenase peptide antibodies. None of these positive individuals had concurrent elevated antibody levels to B27 peptide or pHS-2 peptide. Thus, some Canadian AS patients and RS or reactive arthritis patients showed clear elevations of anti-B27 peptide antibody, whereas differences between controls and patients were not apparent with respect to anti-nitrogenase peptide reactions, confirming our previous observations in two population groups (Norway and USA) (14).

When Canadian patients with reactive arthritis were analyzed with respect to types of antecedent infections, both patients positive for anti-B27 peptide and anti-pHS-2 peptide antibodies were post-Chlamydia arthritis; thus, two out of three HLA-B27(+) male patients with post-Chlamydia arthritis had elevated antibody levels to both peptides. Surprisingly, none of the three Canadian patients with post-Shigella arthri- 


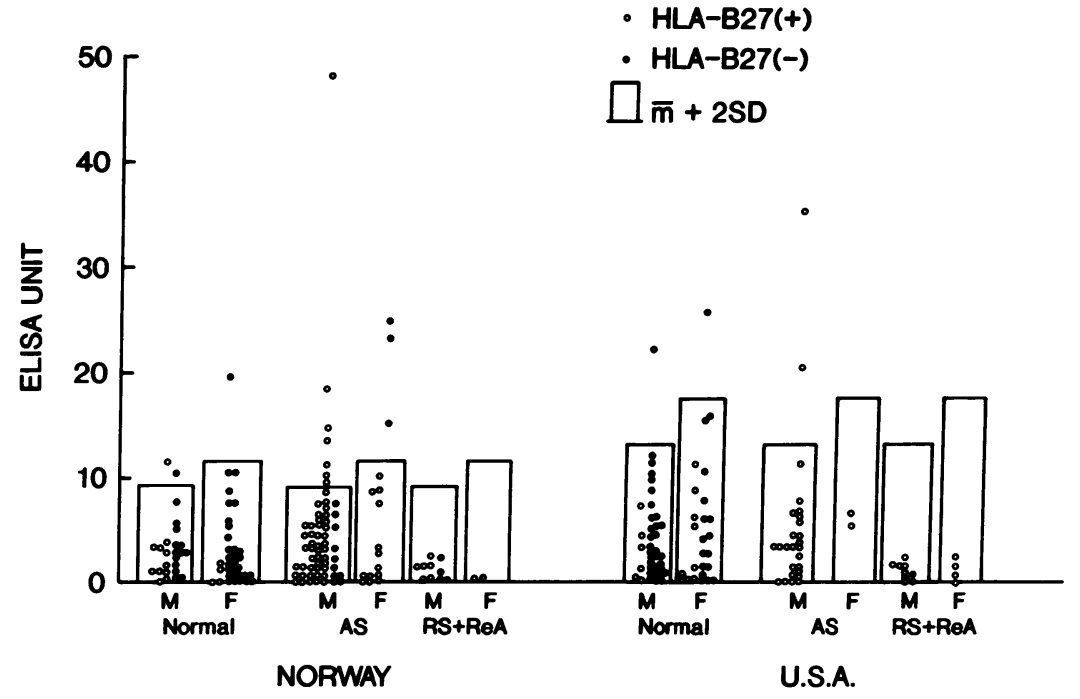

Figure 2. Serum antibody levels of Norwegian and American individuals against synthetic peptide representing amino acid sequence of pHS-2 homologous to HLA-B*2705 antigen. The box shows the mean value $(m)$ plus 2 SD of the respective sex-matched control group (either Norway or USA). (O) HLA-B27 $(+)$ individuals; $(\bullet)$ those negative for HLA-B27. $M$, male; $F$, female; $A S$, ankylosing spondylitis; $R S$, Reiter's syndrome; $R e A$, reactive arthritis. tis [two male and one female, all HLA-B27(+)] showed elevated reactivity to either the B27 or the pHS-2 peptides. Serum from the original Dallas HLA-B27(+) female reactive arthritis patient (from whom the pHS-2 containing $S$. flexneri strain was isolated) also showed no significant reactivity with any of the three peptides.

Correlation between antibody levels to B27 peptide and pHS-2 peptide. As shown in Fig. 4, the antibody levels against B27 peptide and pHS-2 peptide were significantly correlated in HLA-B27(+) patients with AS, RS, or reactive arthritis ( $n$ $=134, r=0.333, P<0.001)$. No significant correlation was observed in HLA-B27(-) patients $(n=26, r=0.169$, NS) or normal controls ( $n=147, r=0.015$, NS). As previously reported (15), the antibody levels to B27 peptide and nitrogenase peptide were not significantly correlated in any of the groups.

Among all 307 normal control and patient sera, 35 showed elevated ELISA reactions with B27 peptide. Sera showing two or three specificities were examined. Among 10 such individuals with elevated anti-B27 peptide antibody, 7 were also positive for anti-pHS-2 peptide and 5 were positive for anti-nitrogenase peptide, including 2 positive for both antipeptide antibodies. The class distributions of the antibodies, as expressed by the relative level compared with normal controls, are shown in Table III. Most of the individuals positive for both anti-B27 peptide and anti-pHS-2 peptide antibodies had IgM-dominant distribution of the antibodies to both peptides. On the other hand, among individuals positive for antibodies to B27 peptide and nitrogenase peptide, the class distribution pattern of the antibodies to both peptides was not similar except for one AS patient N334.

Cross-reactivity of affinity-purified human anti-B27 peptide antibodies. Direct cross-reactivity of affinity-purified human anti-B27 peptide antibodies with pHS-2 peptide and nitrogenase peptide was studied. 15 sera from HLA-B27(+)

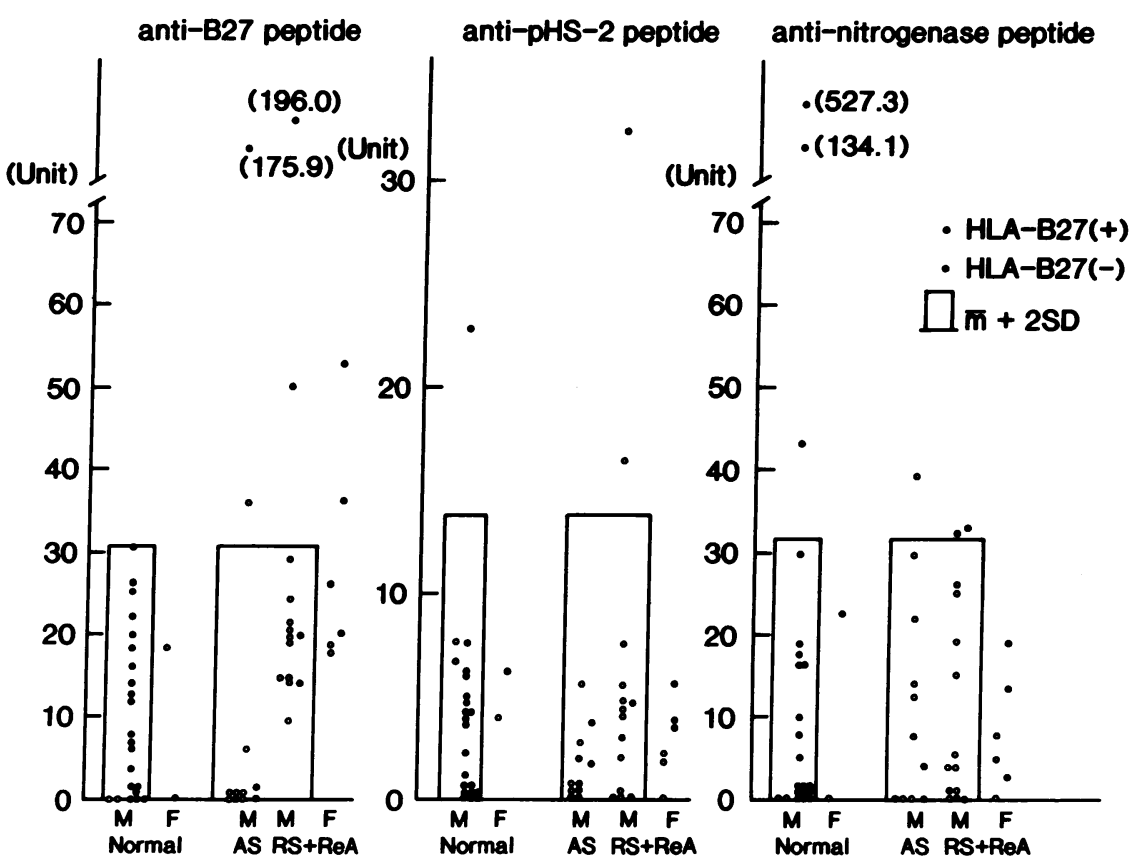

Figure 3. Serum antibody levels of Canadian subjects against synthetic peptides representing residues 69-84 of HLA-B*2705, residues 184-196 of $K$. pneumoniae nitrogenase or pHS- 2 sequence. The box shows the mean value $(\bar{m})$ plus 2 SD of normal male control group. (O) HLA-B27(+) individuals; (•) those negative for HLA-B27. $M$, male; $F$, female; $A S$, ankylosing spondylitis; $R S$, Reiter's syndrome; $R e A$, reactive arthritis. 


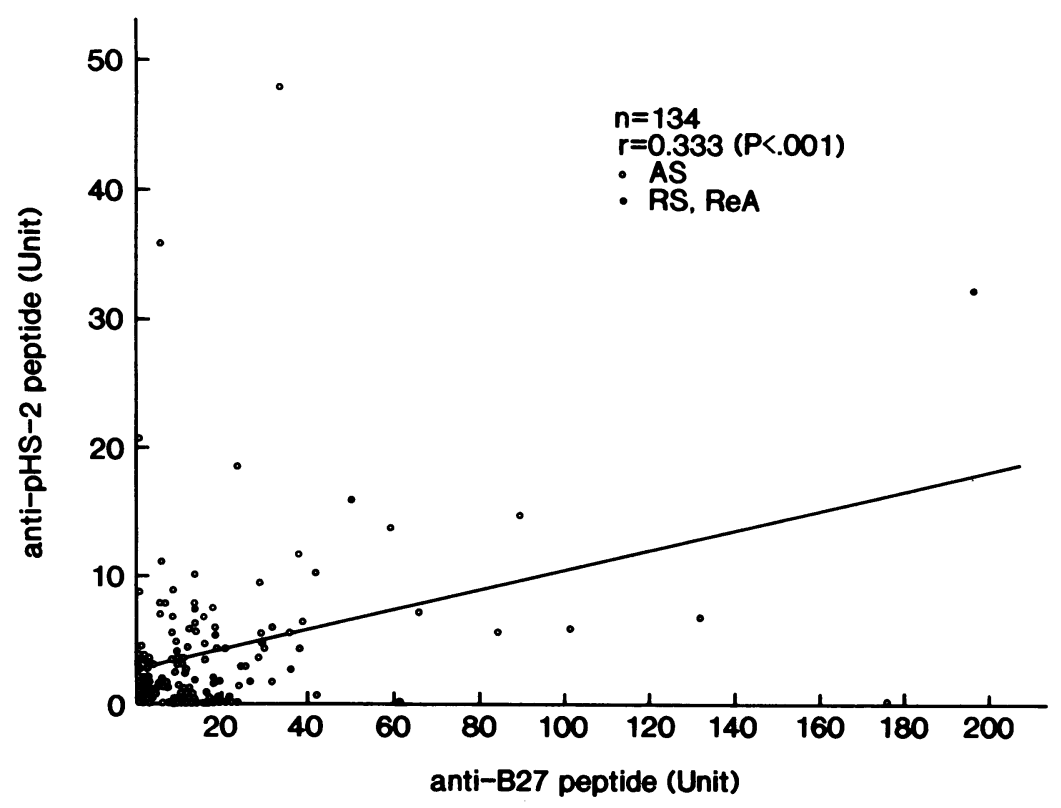

Figure 4. Correlation between anti-B27 peptide and anti-pHS-2 peptide levels in sera from HLA-B27(+) patients. The antibody level against B27 peptide is shown on the abscissa, and that against pHS-2 peptide on the ordinate. $(0)$ Patients with AS; $(\bullet)$ patients with RS or reactive arthritis $(R e A)$. Significant positive correlation was observed between the levels of the antibodies. patients as well as 2 from normal, previously pregnant female controls were examined; all sera were positive for anti-B27 peptide antibody in the whole-serum assay. Cross-reactivity, expressed as percentage of binding to $\mathrm{B} 27$ peptide, was considered to be significant when values were greater than mean plus 3 SD of the percentage of binding to the control P-97 peptide in each individual (Table IV). Significant cross-reaction with the pHS-2 peptide was observed in 13 of 15 affinity-purified samples from patients, including those which were determined to possess only borderline or no reactivity to pHS-2 peptide in the whole-serum assay. On the other hand, only 3 of 15 patients' samples showed weak cross-reactivity with nitrogenase peptide. Although four samples were positive or borderline for nitrogenase peptide in the whole serum assay, only one of them weakly cross-reacted when the purified anti-B27 peptide antibodies were examined (N136), suggesting that the anti-nitrogenase peptide antibodies detected in the whole serum actu- ally belonged to different antibody clones from those producing anti-B27 peptide antibodies. Among the two positive samples from normal female controls, one showed slight but significant cross-reactivity with pHS-2 peptide and nitrogenase peptide (A64). Overall, the average cross-reactivity of purified anti-B27 peptide antibodies with pHS-2 peptide (26.2 $21.3 \%)$ was highly significant when compared with cross-reaction with control P-97 peptide $(4.1 \pm 5.6 \%)(P<0.001)$. In contrast, cross-reactivity with the nitrogenase peptide $(3.1 \pm 3.0 \%)$ was not different from that with P-97 peptide.

There are two amino acids which are shared by HLA-B*2705 and pHS-2 sequences but not by nitrogenase peptide, i.e., alanine (Ala) and leucine (Leu) at positions 71 and 78 of $\mathrm{B}^{*} 2705$ sequence (Table I). To test the possibility that either one or both of these residues was critical for the cross-reactivity, we synthesized three peptides homologous to pHS-2 peptide except either one or both the Ala or Leu had

Table III. Class Distribution of Serum Antipeptide Antibodies from Individuals with Elevated Antibodies to More than One Peptide

\begin{tabular}{|c|c|c|c|c|c|c|c|c|c|}
\hline \multirow{2}{*}{$\begin{array}{l}\text { Sample* } \\
\text { (diagnosis) }\end{array}$} & \multicolumn{3}{|c|}{ Anti-B27 peptide ${ }^{\ddagger}$} & \multicolumn{3}{|c|}{ Anti-pHS-2 peptide } & \multicolumn{3}{|c|}{ Anti-nitrogenase peptide } \\
\hline & $\operatorname{lgG}$ & $\operatorname{Ig} A$ & IgM & IgG & $\operatorname{IgA}$ & IgM & IgG & $\lg A$ & IgM \\
\hline N334 (AS) & 0 & \pm & $1+$ & 0 & 0 & $1+$ & 0 & $3+$ & \pm \\
\hline N1064 (N1) & 0 & 0 & $3+$ & 0 & \pm & $3+$ & $3+$ & $3+$ & 0 \\
\hline N287 (AS) & 0 & $1+$ & $3+$ & 0 & 0 & $3+$ & 0 & 0 & \pm \\
\hline N518 (AS) & 0 & 0 & $3+$ & \pm & $3+$ & $3+$ & 0 & 0 & 0 \\
\hline N797 (AS) & $1+$ & \pm & $3+$ & \pm & 0 & $3+$ & 0 & 0 & 0 \\
\hline $\mathrm{C} 774(\operatorname{ReA})$ & 0 & $1+$ & $3+$ & 0 & $2+$ & $3+$ & 0 & 0 & 0 \\
\hline $\mathrm{C} 11(\operatorname{ReA})$ & $1+$ & 0 & $3+$ & 0 & \pm & \pm & NT & NT & $N T^{\S}$ \\
\hline N212 (AS) & 0 & 0 & $1+$ & 0 & 0 & 0 & \pm & 0 & 0 \\
\hline A44 (AS) & 0 & 0 & $3+$ & 0 & 0 & \pm & $3+$ & 0 & \pm \\
\hline A21 (N1) & $2+$ & 0 & $2+$ & 0 & 0 & 0 & 0 & $3+$ & 0 \\
\hline
\end{tabular}

* Abbreviations: N, Norway; A, America; C, Canada; AS, ankylosing spondylitis; ReA, reactive arthritis; Nl, normal female with previous pregnancy. ${ }^{\ddagger}$ Data on class-specific antipeptide antibody levels in whole serum. $0,<$ normal mean $(\mathrm{m})+1 \mathrm{SD} ; \pm,<\mathrm{m}+2 \mathrm{SD} ; 1+,<\mathrm{m}+3 \mathrm{SD}$; $2+,<\mathrm{m}+4 \mathrm{SD} ; 3+, \geq \mathrm{m}+4 \mathrm{SD}$. ${ }^{\S} \mathrm{NT}$, not tested. The IgG + IgA + IgM antibody level was within normal range. 


\begin{tabular}{|c|c|c|c|c|c|c|c|c|c|c|c|c|c|}
\hline \multirow[b]{3}{*}{$\begin{array}{c}\text { Sample* } \\
\text { (diagnosis) }\end{array}$} & \multirow{2}{*}{\multicolumn{5}{|c|}{ Assay with whole serum ${ }^{\ddagger}$}} & \multicolumn{7}{|c|}{ Percent reactivity of anti-B27 peptide antibody ${ }^{8}$} & \multirow[b]{3}{*}{$\begin{array}{c}\text { Concentration" } \\
\text { assayed } \\
(\mu \mathrm{g} / \mathrm{ml})\end{array}$} \\
\hline & & & & & & \multirow[b]{2}{*}{ B27 } & \multicolumn{4}{|c|}{ pHS-2 } & \multirow[b]{2}{*}{$\begin{array}{l}\text { Nitro- } \\
\text { genase }\end{array}$} & \multirow[b]{2}{*}{ P-97 } & \\
\hline & \multicolumn{3}{|c|}{ Anti-B27 peptide } & $\begin{array}{c}\text { Anti-pHS-2 } \\
\text { peptide } \\
(\mathrm{IgG}+\mathrm{A}+\mathrm{M})\end{array}$ & $\begin{array}{c}\text { Anti-nitrogenase } \\
\text { peptide } \\
(\operatorname{IgG}+\mathrm{A}+\mathrm{M})\end{array}$ & & $\begin{array}{l}\text { Original } \\
\text { (A2L9) }\end{array}$ & R2L9 & A2E9 & R2E9 & & & \\
\hline & & & & & & & & & & & & & $\mu g / m l$ \\
\hline N232 (AS) & 0 & $3+$ & 1 & \pm & 0 & 100 & $\underline{16.8}$ & $\underline{23.1}$ & 0 & 0 & 0.7 & 1.3 & 1.0 \\
\hline N287 (AS) & 0 & $1+$ & $3+$ & $2+$ & 0 & 100 & $\underline{24.8}$ & NT & NT & NT & $\underline{4.3}$ & 0 & 0.1 \\
\hline N678 (AS) & $1+$ & 0 & 0 & \pm & 0 & 100 & $\underline{51.7}$ & $\underline{59.0}$ & 0 & 0 & 0 & 3.8 & 0.4 \\
\hline N797 (AS) & $1+$ & \pm & $3+$ & $2+$ & 0 & 100 & $\underline{64.5}$ & $\underline{100.2}$ & 9.7 & 13.5 & 11.1 & 13.7 & 1.0 \\
\hline A7 (AS) & \pm & 0 & $3+$ & \pm & 0 & 100 & $\underline{38.8}$ & NT & NT & NT & $\underline{2.9}$ & 1.7 & 7.2 \\
\hline $\mathrm{C} 774(\operatorname{ReA})$ & 0 & $1+$ & $3+$ & $3+$ & 0 & 100 & $\underline{41.5}$ & $\underline{55.4}$ & 3.9 & 0.8 & $\overline{2.7}$ & 7.4 & 0.3 \\
\hline N620 (N1) & $3+$ & 0 & 0 & \pm & 0 & 100 & $\overline{5.3}$ & $\underline{21.9}$ & 1.0 & 2.7 & 3.7 & 5.0 & 0.1 \\
\hline N136 (AS) & $1+$ & 0 & 0 & 0 & \pm & 100 & $\underline{8.4}$ & NT & NT & NT & $\underline{1.8}$ & 0 & 0.3 \\
\hline N212 (AS) & 0 & 0 & $1+$ & 0 & $1+$ & 100 & $\underline{11.1}$ & NT & NT & NT & $\overline{6.6}$ & 5.3 & 0.5 \\
\hline N334 (AS) & 0 & \pm & $1+$ & $1+$ & $3+$ & 100 & 24.7 & $\underline{59.1}$ & 9.4 & 6.7 & 4.2 & 20.5 & 1.0 \\
\hline A44 (AS) & 0 & 0 & $3+$ & 0 & $2+$ & 100 & $\underline{28.5}$ & $\underline{40.5}$ & 0 & 0 & 5.6 & 0.4 & 2.0 \\
\hline N34 (AS) & $3+$ & 0 & 0 & 0 & 0 & 100 & $\underline{15.5}$ & $\underline{94.0}$ & 0 & 0 & 0 & 0.5 & 2.0 \\
\hline N35 (AS) & 0 & 0 & $3+$ & 0 & 0 & 100 & 3.2 & $\underline{22.3}$ & 0 & 0 & 0 & 1.6 & 1.0 \\
\hline N71 (AS) & 0 & $3+$ & 0 & 0 & 0 & 100 & $\underline{8.4}$ & $\overline{43.2}$ & 0 & 0 & 0 & 0 & 2.0 \\
\hline N578 (AS) & 0 & 0 & $3+$ & 0 & 0 & 100 & $\underline{73.2}$ & $\underline{127.1}$ & 3.8 & 3.8 & 5.1 & 6.4 & 0.6 \\
\hline N728 (AS) & 0 & 0 & $3+$ & 0 & 0 & 100 & $\underline{\underline{25.8}}$ & $\underline{73.4}$ & 0 & 0 & 0 & 0 & 2.0 \\
\hline A64 (Nl) & $3+$ & 0 & 0 & 0 & 0 & 100 & $\underline{4.3}$ & $\underline{11.6}$ & 2.4 & 1.4 & $\underline{4.3}$ & 2.8 & 0.2 \\
\hline \multirow{2}{*}{\multicolumn{7}{|c|}{ Average cross-reactivity (mean $\pm \mathrm{SD}$ ) }} & 26.3 & 56.2 & 2.3 & 2.2 & 3.1 & 4.1 & \\
\hline & & & & & & & \pm 21.3 & \pm 34.8 & \pm 3.5 & \pm 3.9 & \pm 3.0 & \pm 5.6 & \\
\hline
\end{tabular}

\footnotetext{
* Abbreviations: N, Norway; A, America; C, Canada; AS, ankylosing spondylitis; ReA, reactive arthritis; Nl, normal female with previous pregnancy. ${ }^{\ddagger}$ Data on anti-B27 peptide and anti-nitrogenase peptide antibodies are from published results $(15) .0,<$ normal mean $(\overline{\mathrm{m}})+1 \mathrm{SD} ; \pm$, $<\overline{\mathrm{m}}+2 \mathrm{SD} ; 1+,<\overline{\mathrm{m}}+3 \mathrm{SD} ; 2+,<\overline{\mathrm{m}}+4 \mathrm{SD} ; 3+, \geq \overline{\mathrm{m}}+4 \mathrm{SD} .{ }^{\S}$ Binding to each peptide, expressed as percentage of binding to B27 peptide. Significant cross-reactions ( $>\overline{\mathrm{m}}+3 \mathrm{SD}$ of the binding to P-97 in the individual sample) are underscored. NT, not tested. "Final concentration of each purified antibody tested, measured by ELISA. In order to detect all possible cross-reactivity, the maximum concentration available for each antibody solution was used.
}

been replaced by arginine (Arg) or glutamic acid (Glu), which appeared at the corresponding position in nitrogenase peptide (Table I). In all 13 samples tested, significant cross-reactivity was observed against the peptide with the single substitution Ala $\rightarrow$ Arg (designated R2L9), however, cross-reactivity was abrogated in the two peptides which included a substitution Leu $\rightarrow$ Glu, regardless of the presence of Ala $\rightarrow$ Arg substitution (A2E9, R2E9) (Table IV). Of great interest, in all samples tested, R2L9 peptide had even higher cross-reactivity than the original pHS-2 peptide showed with the anti-B27 peptide antibodies. Thus, the average cross-reactivity with R2L9 peptide $(56.2 \pm 34.8 \%)$ was significantly higher than that with the original pHS-2 peptide $(26.3 \pm 21.3 \%)(P<0.01)$.

Some experiments were repeated with the peptides airdried in the microtiter plate wells so that the identical quantity of the various peptides were uniformly coated on the plates. The results were essentially identical.

Binding of anti-B27 peptide antibodies to $H L A-B 27-$ transfected mouse $L$ cells. Whether the purified human antiB27 peptide antibodies bind to the whole HLA-B27 molecule was examined by CELISA. In order to avoid nonspecific binding due to surface human immunoglobulins and Fc receptors, mouse $L$ cells doubly transfected with HLA-B*2705 and human $\beta_{2}$-microglobulin genes were used. $L$ cells transfected only with $\beta_{2}$-microglobulin gene were used as controls. Results are shown in Table V. IgG dominant anti-B27 peptide antibody from patient N34 bound significantly stronger to B27transfected cells than to the cells transfected only with $\beta_{2}$-microglobulin at all concentrations tested. Control IgG showed slightly enhanced binding to B27-transfected cells at the highest concentration, but no significant difference was observed at lower concentrations. Among four IgM dominant anti-B27 peptide antibodies examined, one (A44) showed significantly stronger binding to B27-transfected cells, while other patients' antibodies and control polyclonal IgM did not show significant differences. Mouse MAb ME1 reacted strongly to B27 transfected cells, while MOPC $31 \mathrm{C}$ (control IgG 1) did not.

To exclude the possibility that a different number of the cells were adhering in the wells after the washing procedures essential for CELISA, the dye-binding assay was performed to estimate the protein quantity within the wells after vigorous washing. No difference was observed between two transfected cell lines (Table V).

Anti-pHS-2 peptide antibody binding to Shigella strains. Whole Shigella bacteria as well as bacterial membrane and cytosol fractions were assayed by ELISA using affinity-purified rabbit anti-pHS-2 peptide antibody to determine whether plasmid-positive strains presumably responsible for enhanced 
Table V. CELISA Results Showing the Binding of Affinity-purified Human Anti-B27 Peptide Antibody to the Transfected L Cell Lines

\begin{tabular}{|c|c|c|c|}
\hline & \multicolumn{2}{|c|}{$\begin{array}{l}\text { Binding to transfected cells } \\
\quad \text { (mean } \mathrm{OD} \pm \mathrm{SD})\end{array}$} & \multirow[b]{2}{*}{$P^{\ddagger}$} \\
\hline & $\begin{array}{c}\beta_{2} \text {-microglobulin } \\
\text { only }\end{array}$ & $\begin{array}{c}\text { HLA-B27 and } \\
\beta_{2} \text {-microglobulin }\end{array}$ & \\
\hline \multicolumn{4}{|l|}{ IgG class antibodies } \\
\hline \multicolumn{4}{|l|}{ N34 (AS) } \\
\hline $0.5 \mathrm{~g} / \mathrm{ml}$ & $0.084 \pm 0.008$ & $0.115 \pm 0.002$ & $<0.01$ \\
\hline $1.0 \mathrm{~g} / \mathrm{ml}$ & $0.170 \pm 0.015$ & $0.240 \pm 0.010$ & $<0.01$ \\
\hline $2.0 \mathrm{~g} / \mathrm{ml}$ & $0.302 \pm 0.024$ & $0.434 \pm 0.022$ & $<0.01$ \\
\hline \multicolumn{4}{|c|}{ Control IgG (Cohn fraction II) } \\
\hline $0.5 \mathrm{~g} / \mathrm{ml}$ & $0.031 \pm 0.008$ & $0.042 \pm 0.001$ & NS \\
\hline $1.0 \mathrm{~g} / \mathrm{ml}$ & $0.060 \pm 0.005$ & $0.071 \pm 0.007$ & NS \\
\hline $2.0 \mathrm{~g} / \mathrm{ml}$ & $0.110 \pm 0.005$ & $0.135 \pm 0.005$ & $<0.01$ \\
\hline \multicolumn{4}{|l|}{ IgM class antibodies $(0.1 \mathrm{~g} / \mathrm{ml})$} \\
\hline N728 (AS) & $0.189 \pm 0.031$ & $0.176 \pm 0.014$ & NS \\
\hline N797 (AS) & $0.105 \pm 0.012$ & $0.109 \pm 0.003$ & NS \\
\hline A7 (AS) & $0.199 \pm 0.022$ & $0.178 \pm 0.007$ & NS \\
\hline A44 (AS) & $0.203 \pm 0.012$ & $0.253 \pm 0.015$ & $<0.02$ \\
\hline Control polyclonal IgM & $0.056 \pm 0.005$ & $0.064 \pm 0.010$ & NS \\
\hline \multicolumn{4}{|l|}{$\begin{array}{l}\text { Mouse monoclonal antibodies } \\
(20 \mathrm{~g} / \mathrm{ml})\end{array}$} \\
\hline MEI & $0.341 \pm 0.008$ & $0.656 \pm 0.034$ & $<0.00$ \\
\hline MOPC $31 \mathrm{C}$ & $0.117 \pm 0.021$ & $0.140 \pm 0.008$ & NS \\
\hline Dye-binding protein assay* & $0.492 \pm 0.053$ & $0.484 \pm 0.066$ & NS \\
\hline
\end{tabular}

The reactivity of patients' affinity-purified anti-B27 peptide antibodies with the mouse $L$ cell lines transfected with HLA-B27 and $\beta_{2}$-microglobulin was tested by CELISA as described in Methods.

* The protein quantity remaining in the wells after vigorous washing procedures was estimated by dye-binding assay as described in Methods. The results are expressed as mean $\mathrm{OD}_{630} \pm \mathrm{SD}$.

* Statistical significance of the difference between binding to the cells transfected with HLA-B27 and $\beta_{2}$-microglobulin vs. binding to the cells transfected with $\beta_{2}$-microglobulin alone.

expression of HLA-B27 cross-reactive epitopes showed enhanced reactivity with antibody to pHS-2 peptide. Six experiments were performed using intact IgG from affinity-purified rabbit anti-pHS-2 peptide and control normal rabbit IgG and two experiments with pepsin digested $F\left(\mathrm{ab}^{\prime}\right)_{2}$ fragments of the same preparations.

As shown in Fig. 5, anti-pHS-2 peptide antibody showed strong reactivity with plasmid-positive strain 6115 , while weak reactivity with normal rabbit IgG was present. Another plasmid-positive strain EDL showed moderate reactivity with anti-pHS-2 peptide and no binding with normal rabbit IgG. Surprisingly, two plasmid-negative strains $(\mathrm{C} 1250,7561)$ also showed moderate reactivity with anti-pHS-2 peptide. They also showed higher reactivity with normal rabbit IgG than in the case with plasmid-positive strains.

Similar results were obtained with whole bacteria, membrane or cytosol preparations, and likewise similar findings were noted using intact antibody or $\mathrm{F}\left(\mathrm{ab}^{\prime}\right)_{2}$ fragments. Thus, the strong binding between anti-pHS- 2 peptide antibody and plasmid-positive strain 6115 suggested the presence of pHS-2 peptide sequence on the bacterial membrane, however, data obtained with plasmid-negative strains also suggested the presence of cross-reacting epitopes on membrane regardless of whether the strains contained the pHS- 2 plasmid.

To address this question more directly, a series of compara-

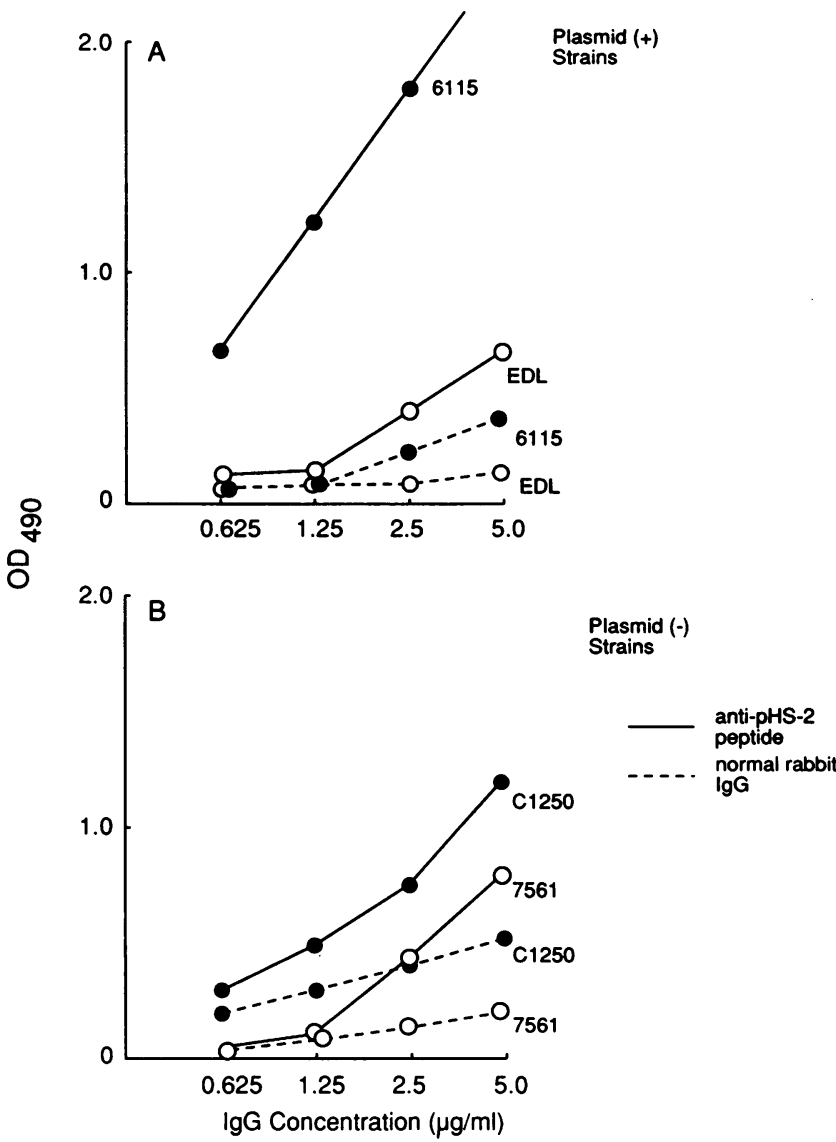

Figure 5. ELISA reactivity of affinity-purified rabbit anti-pHS-2 peptide antibody with bacterial membrane from two pHS-2 plasmidpositive Shigella strains ( $A: 6115, \mathrm{EDL})$ in parallel with two plasmidnegative strains $(B: C 1250,7061)$. Distinct reactivity with anti-pHS2 peptide was demonstrated in strain 6115 (plasmid-positive) compared with reaction with normal rabbit IgG. In two plasmid-negative strains, moderate reactivity with anti-pHS- 2 peptide was shown. Also, higher normal rabbit IgG binding was observed in plasmid-negative strains.

tive immunoprecipitation experiments using plasmid-positive or negative Shigella strains were performed. Both pHS-2 plasmid-positive and negative strains showed several components reacting with affinity-purified anti-pHS-2 peptide antibody. No consistent difference in autoradiograph patterns was noted when plasmid-positive and plasmid-negative Shigella strains were compared.

Studies with human affinity-purified anti-B27 antibodies. Similar comparisons were next made using six different affinity purified human anti-HLA B27 antibodies (Tables III and IV) added to ELISA plates coated with plasmid-positive arthritogenic Shigella and plasmid-negative neutral strains. Only one of six human affinity-purified anti-HLA B27 antibodies showed positive reactions with Shigella. The antibody was derived from a patient with classic AS. No significant difference in reactivity between plasmid-positive and plasmidnegative Shigella strains was noted. Thus, the human antibody reacting with HLA-B27 epitopes failed to distinguish between arthritogenic Shigella strains and those not associated with reactive arthritis. 


\section{Discussion}

In the present study, we have demonstrated the presence of serum antibodies in some patients with AS or reactive arthritis, which reacted with synthetic peptides representing the polymorphic region of HLA-B27 antigen or a homologous putative sequence derived from the DNA nucleotide sequence of a plasmid isolated from $S$. flexneri strains associated with reactive arthritis. It is still not yet clear whether the pHS-2 peptide is actually expressed during reactive arthritis in these cases. 13 of 15 affinity-purified anti-B27 peptide antibodies from patients showed strong cross-reactivity with pHS-2 peptide, whereas only 3 of the 15 only weakly cross-reacted with Klebsiella nitrogenase peptide. One of the two anti-B27 peptide antibodies from normal female controls with previous pregnancy showed only weak cross-reaction with the pHS- 2 and the nitrogenase peptides. These results may suggest that, although both the Klebsiella nitrogenase and pHS-2 share a similar degree of primary sequence homology (Table I), pHS-2 peptide "mimics" the B27 sequence epitope in a way more efficiently recognizable by human B cells than is the case with the nitrogenase peptide. Although the finding of definite antiHLA-B27 peptide reactivity in the 15 patient sera studied in Table IV provides clear evidence for the degree of cross-reactivity of such affinity-isolated human antibodies for other similar sequential epitopes, it does not provide direct insight into how such patients actually are capable of making antibodies against antigenic epitopes theoretically contained within their own MHC phenotypes. Actually the data presented in Figs. 2 and 3 show that with the putative pHS-2 peptide, a relatively low level of reactivity can be demonstrated even when large numbers of AS and RS/reactive arthritis patients are studied. Moreover, the data presented here combined with our previous work (15) indicate that only a minority of patients can be shown to have humoral antibody to B27 peptide or similar cross-reacting sequences.

However, the finding that a proportion of patients have antibodies to HLA-B27 sequence which cross-react with the putative sequence encoded by the plasmid represents a finding of considerable interest, because plasmids can be exchanged among various Enterobacteriaceae. It is well known that various microorganisms including Shigella, Salmonella, Campylobacter, Yersinia, and Chlamydia may be involved in the pathogenesis of reactive arthritis (23). Unexpectedly, antibodies to B27 peptide and pHS-2 peptide were elevated in two out of three HLA-B27(+) male post-Chlamydia arthritis patients, while none of the four post-Shigella arthritis patients, including one patient from whom the $S$. flexneri strain with the pHS-2 plasmid was isolated, were positive for the antibodies. These data could suggest that a DNA sequence encoding a pHS-2-like peptide is expressed by arthritogenic Chlamydia strains. Also, further study with a larger number of patients will be necessary in order to assess whether pHS-2 may be involved in the pathogenesis of post-Shigella arthritis.

It has already been recognized that, in reactions between peptide antigens and antipeptide antibodies, the degree of amino acid sequence homology does not always correlate with the degree of antigenic cross-reactivity (24). Extensive studies by Getzoff et al. (25), during which one amino acid residue within a hexamer peptide was systematically replaced with one of the other 19 residues, revealed that some residues appeared to be critical for binding to antibodies raised against the original protein, whereas replacement of other residues did not result in significant reduction of the reactivity. Our data obtained using pHS- 2 analogue peptides clearly indicated that leucine, in the context of QTDR sequence, was critical for the cross-reactivity. Unexpectedly, the peptide with Ala $\rightarrow$ Arg substitution (R2L9) more strongly cross-reacted with anti-B27 peptide antibodies than did the original pHS- 2 peptide. This phenomenon might be related to the biochemical similarity between arginine and lysine (which latter is found at position 70 of the B27 sequence), because both have positively charged polar side chains. This point must also be considered in terms of the critical leucine residue, since the Klebsiella nitrogenase peptide also has arginine at the same position but failed to cross-react with human sera.

The explanations for the discrepancy between the present study and the study by Schwimmbeck et al. (9) with respect to anti-nitrogenase peptide antibody were discussed in our previous paper (15). Firstly, in the original study the cross-reactivity of human antipeptide antibodies had not been demonstrated by methods such as correlation analysis, inhibition, or affinity-purification. Secondly, procedures to correct for nonspecific binding which varies from serum to serum were not clearly mentioned in the original study, whereas we always used peptide-uncoated wells for every serum sample as negative controls (15). This kind of procedure seems to be essential in the ELISA for the antigen-specific antibodies since the presence of antibodies that bind to plastic assay plates has been clearly demonstrated (26). Methods similar to ours which provide an internal correction for nonspecific adsorption have already been used by other investigators (27).

Our CELISA results indicated that at least a proportion of patients' anti-B27 peptide antibodies were capable of binding to the native HLA-B*2705 molecule. This agrees with our previous observations using rat antipeptide antibodies (13), and those by Rojo et al. (28), which demonstrated rabbit antibody to 63-84 peptide of HLA-B*2705 molecule were cytotoxic to HLA-B*2705 lymphoblastoid cell lines. Whether the absence of significant reaction of the other anti-B27 peptide antibodies was due to the actual lack of binding capability of our assay conditions is not yet clear. Slightly enhanced binding of the pooled human IgG (Cohn fraction II) to the B27-transfected cells could be related to the presence of anti-class I antibodies among normal females with previous pregnancy $(14,29)$.

One of the possibilities suggested by the present study is that bacterial plasmid components such as pHS-2 could play a role in initiating disease through a mechanism of molecular mimicry. Patients with elevated anti-B27 peptide antibodies without significant cross-reaction to $\mathrm{pHS}-2$ peptide could have been triggered by other microorganisms such as $Y$. pseudotuberculosis with cross-reaction with the same region on HLA-B27 antigen (7).

Alternatively, it might also be possible that antibodies to HLA-B27 polymorphic region are produced by a genuine autoimmune mechanism, and that the cross-reactions with various bacterial components are merely an apparent phenomenon without pathogenic significance. Autoantibodies to HLAclass II antigen have been described in patients with systemic lupus erythematosus (30). Finally, anti-B27 peptide antibodies could originally be directed at B27 polymorphic regions 
modified by binding with some endogenous or exogenous ligands, as postulated by Seager et al. (31) and Geczy et al. (32, 33). Crystallographic studies have suggested that the amino acid sequence of the HLA-B27 antigen studied in this report corresponds to a part of the presumed antigen-peptide binding cleft $(34,35)$. Also, the possible role of the unpaired cysteine residue at position 67 in interacting with ligands has been suggested (20). All of these possibilities are not mutually exclusive.

As noted above it still is not clear whether the cross-reacting pHS-2 peptide encoded by the plasmid DNA sequence is expressed in the Shigella strains in question. Direct testing of plasmid-positive and negative strains with affinity-purified rabbit anti-pHS-2 antibody showed strong reactions with several of the plasmid-positive strains, however, moderate reactions were also noted when plasmid-negative strains were used. These results may support the possibility of multiple crossreacting epitopes recognized by the rabbit antibody regardless of the presence of pHS-2 plasmid. Similar observations were reported by Raybourne et al. (8) using anti-HLA MAbs.

Most relevant is the problem that expression of the pHS-2 peptide in vivo in bacteria within the infected patient may not be comparable to that with the same bacterial strains cultivated in vitro. An alternative answer to the problem of identifying links or clues to molecular mimicry in this situation was therefore to examine affinity-purified anti-B27 human antibody to determine whether such populations would show selective reactions with arthritogenic plasmid-positive Shigella strains. Only one of six affinity-isolated human anti-B27 antibodies reacted with Shigella strains; however, this antibody did not differentiate between arthritogenic and nonarthritogenic organisms. The question must remain open since the antibody was derived from a patient with AS. Ideally the same experiment eventually needs to be repeated using anti-B27reacting antibody obtained from a patient with shigellosis and reactive arthritis.

How naturally occurring anti-B27 peptide antibodies are related to the pathological process still remains speculative. Our preliminary results of microcytotoxicity assay using HLA-B27 lymphocytes did not show significant cytotoxicity in the sera from patients with AS (data not shown). It is likely, therefore, that the antibodies bind to the class I molecule and could modify cellular functions, rather than directly damaging the tissues through complement mediated lysis. Class I MHC molecules have reportedly been implicated in $\mathrm{T}$ cell activation (36). The presence of antibodies to class I molecules thus could possibly result either in proliferative signals through crosslinking of class I molecules or inhibitory effects through blocking of activation signals. The latter mechanism might explain the impaired cellular immunity in patients with reactive arthritis after Salmonella typhimurium infection (37). Immune complexes formed by soluble HLA-class I antigens (38) and anti-class I antibodies might also be involved. The strong expression of this sequential epitope on synovial tissues might partially explain the tissue localization of the inflammation (13). Prolonged persistence of chlamydia or yersinia antigens within synovial tissue or synovial-fluid cells has been reported (39-42), suggesting the possibility of local molecular mimicry phenomena.

The present study provides evidence for cross-reactivity of hypothetical pHS-2 sequence with the HLA-B27 molecule.
Additional studies using pHS- 2 as well as other bacterial epitopes may eventually clarify the relationship between HLA-B27, antecedent infection and development of spondylarthropathies.

\section{Acknowledgments}

The authors want to thank Dr. Joel D. Taurog for providing the transfected cell lines and the ME1 monoclonal antibody. We are also indebted to Tamaki Tsuchiya for technical assistance, Karen Crandall and Suzanne Smith for typing the manuscript.

This work was supported by grant AMAI-13690 from the National Institutes of Health, a grant from the Arthritis Society, and in part, a grant from the North Texas Chapter of the Arthritis Foundation.

\section{References}

1. Keat, A. 1986. Is spondylitis caused by Klebsiella? Immunol. Today. 7:144-149.

2. Welsh, J., H. Avakian, P. Cowling, A. Ebringer, P. Wooley, G. Panayo, and R. Ebringer. 1980. Ankylosing spondylitis, HLA-B27 and Klebsiella. I. Cross-reactivity studies with rabbit antisera. Br. J. Exp. Pathol. 61:85-91.

3. Avakian, H., J. Welsh, A. Ebringer, and C. C. Entwistle. 1980. Ankylosing spondylitis, HLA-B27 and Klebsiella. II. Cross-reactivity studies with human tissue typing sera. Br. J. Exp. Pathol. 61:92-96.

4. Trull, A., A. Ebringer, G. Panayi, R. Ebringer, and D. C. O. James. 1984. HLA-B27 and the immune response to enterobacterial antigens in ankylosing spondylitis. Clin. Exp. Immunol. 55:74-80.

5. Van Bohemen, C. G., F. C. Brumet, and H. C. Zanen. 1984. Identification of HLA-B27M1 and -M2 cross-reactive antigens in Klebsiella, Shigella and Yersinia. Immunology. 52:607-610.

6. Kono, D. H., M. Ogasawara, R. B. Effros, M. S. Park, R. L. Valdord, and D. T. Y. Yu. 1985. Ye-1, a monoclonal antibody that cross-reacts with HLA-B27 lymphoblastoid cell lines and an arthritis causing bacteria. Clin. Exp. Immunol. 61:503-508.

7. Chen, J.-H., D. Kono, Z. Yong, M. S. Park, M. B. A. Oldstone, and D. T. Y. Yu. 1987. A Yersinia pseudotuberculosis protein which cross-reacts with HLA-B27. J. Immunol. 139:3003-3011.

8. Raybourne, R. B., V. K. Bunning, and K. M. Williams. 1988. Reaction of anti-HLA-B monoclonal antibodies with envelope proteins of Shigella species: evidence for molecular mimicry in the spondyloarthropathies. J. Immunol. 140:3489-3495.

9. Schwimmbeck, P. L., D. T. Y. Yu, and M. B. A. Oldstone. 1987. Autoantibodies to HLA B27 in the sera of HLA B27 patients with ankylosing spondylitis and Reiter's syndrome: molecular mimicry with Klebsiella pneumoniae as potential mechanism of autoimmune disease. J. Exp. Med. 166:173-181.

10. WHO-HLA Nomenclature Committee. 1988. Nomenclature for factors of the HLA system, 1987. Vox Sang. 55:119-126.

11. Sundaresan, V., and F. M. Ausubel. 1981. Nucleotide sequence of the gene coding for the nitrogenase iron protein from Klebsiella pneumoniae. J. Biol. Chem. 256:2808-2812.

12. Aparicio, P., S. Rojo, D. Jaraquemada, and J. Lopez de Castro. 1987. Fine specificity of HLA-B27 cellular allorecognition: HLA-B27f is a functional variant distinguishable by cytolytic $\mathrm{T}$ cell clones. $J$. Immunol. 139:837-841.

13. Stieglitz, H., S. Fosmire, and P. E. Lipsky. 1989. Identification of a 2-Md plasmid from Shigella flexneri associated with reactive arthritis. Arthritis Rheum. 32:937-946.

14. Husby, G., N. Tsuchiya, P. L. Schwimmbeck, A. Keat, J. A. Pahle, M. B. A. Oldstone, and R. C. Williams, Jr. 1989. Cross-reactive epitope with Klebsiella pneumoniae nitrogenase in articular tissue of HLA-B27(+) patients with ankylosing spondylitis. Arthritis Rheum. 32:437-445.

15. Tsuchiya, N., G. Husby, and R. C. Williams, Jr. 1989. Studies of humoral and cell-mediated immunity to peptides shared by 
HLA-B27.1 and Klebsiella pneumoniae nitrogenase in ankylosing spondylitis. Clin. Exp. Immunol. 76:354-360.

16. Stieglitz, H., S. Fosmire, and P. E. Lipsky. 1988. Bacterial epitopes involved in the induction of reactive arthritis. Am. J. Med. 85(Suppl. 6A):56-58.

17. Bennett, P. H., and T. A. Burch. 1967. New York symposium on population studies in the rheumatic diseases: new diagnostic criteria. Bull. Rheum. Dis. 7:453-458.

18. Inman, R. D., B. Chiu, M. E. A. Johnston, and J. Falk. 1986. Molecular mimicry in Reiter's syndrome: cytotoxicity and ELISA studies of HLA-microbial relationships. Immunology. 58:501-506.

19. Merrifield, R. B. 1969. Solid-phase peptide synthesis. Adv. Enzymol. 32:221-296.

20. Taurog, J. D., and F. A. K. El-Zaatari. 1988. In vitro mutagenesis of HLA-B27: substitution of an unpaired cysteine residue in the $\alpha_{1}$ domain causes loss of antibody-defined epitopes. J. Clin. Invest. 82:987-992.

21. Baumgarten, H. 1986. A cell ELISA for the quantitation of leukocyte antigens: requirements for calibration. J. Immunol. Methods. 94:91-98.

22. Portnoy, D. A., H. Wolf-Watz, I. Bolin, A. B. Beeder, and S. Falkow. 1984. Characterization of common virulence plasmids in Yersinia species and their role in the expression of outer membrane proteins. Infect. Immun. 43:108-114.

23. Keat, A. 1983. Reiter's syndrome and reactive arthritis in perspective. N. Engl. J. Med. 309:1606-1615.

24. Dyrberg, T., and M. B. A. Oldstone. 1986. Peptides as probes to study molecular mimicry and virus-induced autoimmunity. Curr. Top. Microbiol. Immunol. 130:25-37.

25. Getzoff, E. D., J. A. Tainer, R. A. Lerner, and H. M. Geysen 1988. The chemistry and mechanism of antibody binding to protein antigens. Adv. Immunol. 43:1-98.

26. Conger, J. D., B. L. Pike, and G. J. V. Nossal. 1988. Analysis of the B lymphocyte repertoire by polyclonal activation: hindrance by clones yielding antibodies which bind promiscuously to plastic. J. Immunol. Methods. 106:181-189.

27. Cavender, D., and M. Ziff. 1986. Anti-HLA-B27 antibodies in sera from patients with gram-negative bacterial infections. Arthritis Rheum. 29:352-357.

28. Rojo, S., J. A. Lopez de Castro, P. Aparicio, G. Van Seventer, and R. Bragado. 1986. HLA-B27 antigenicity: antibodies against the chemically synthesized 63-84 peptide from HLA-B27.1 display alloantigenic specificity and discriminate among HLA-B27 subtypes. $J$. Immunol. 137:904-910.

29. Ahrons, S. 1971. HL-A antibodies: influence on the human foetus. Tissue Antigens. 1:129-136.
30. Okudaira, K., R. P. Searles, J. L. Ceuppens, J. S. Goodwin, and R. C. Williams, Jr. 1982. Anti-Ia reactivity in sera from patients with systemic lupus erythematosus. J. Clin. Invest. 69:17-24.

31. Seager, K., H. V. Bashir, A. F. Geczy, J. Edmonds, and A. de Vere-Tyndall. 1979. Evidence for a specific B27-associated cell surface marker on lymphocytes of patients with ankylosing spondylitis. Nature (Lond.). 277:68-70

32. Geczy, A. F., K. Alexander, H. V. Bashir, and J. Edmonds. 1980. A factor(s) in Klebsiella culture filtrates specifically modifies an HLA B27-associated cell-surface component. Nature (Lond.). 283:782-784.

33. Geczy, A. F., K. Alexander, H. V. Bashir, J. P. Edmonds, L. Upfold, and J. Sullivan. 1983. HLA-B27, Klebsiella and ankylosing spondylitis: biological and chemical studies. Immunol. Rev. 70:23-50.

34. Bjorkman, P. J., M. A. Saper, B. Samraoui, W. S. Bennett, J. L. Strominger, and D. C. Wiley. 1987. Structure of the human class I histocompatibility antigen, HLA-A2. Nature (Lond.). 329:506-512.

35. Bjorkman, P. J., M. A. Saper, B. Samraoui, W. S. Bennett, J. L. Strominger, and D. C. Wiley. 1987. The foreign antigen binding site and $\mathrm{T}$ cell recognition regions of class $\mathrm{I}$ histocompatibility antigens. Nature (Lond.). 329:512-518.

36. Geppert, T. D., M. C. Wacholtz, S. S. Patel, E. Lightfoot, and P. E. Lipsky. 1989. Activation of human T cell clones and Jurkat cells by cross-linking class I MHC molecules. J. Immunol. 142:3763-3772.

37. Inman, R. D., B. Chiu, M. E. A. Johnston, S. Vas, and J. Falk. 1989. HLA class I-related impairment in IL-2 production and lymphocyte response to microbial antigens in reactive arthritis. $J$. Immunol. 142:4256-4260.

38. Gussow, D., and H. Ploegh. 1987. Soluble class I antigens: a conundrum with no solution? Immunol. Today. 8:220-222.

39. Ishikawa, H., O. Ohno, K. Yamasaki, S. Ikuta, and K. Hirohata. 1986. Arthritis presumably caused by Chlamydia in Reiter syndrome. Case report with electron microscopic studies. J. Bone Joint Surg. 68A:777-779.

40. Keat, A., B. Thomas, J. Dixey, M. Osborn, C. Sonnex, and D. Taylor-Robinson. 1987. Chlamydia trachomatis and reactive arthritis: the missing link. Lancet. $i: 72-74$.

41. Schumacher, H. R. Jr., S. Magge, V. Cherian, J. Sleckman, S. Rothfuss, G. Clayburne, and M. Sieck. 1988. Light and electron microscopic studies on the synovial membrane in Reiter's syndrome: immunocytochemical identification of chlamydial antigen in patients with early disease. Arthritis Rheum. 31:937-946.

42. Granfors, K., S. Jalkanen, R. von Essen, R. Lahesmaa-Rantala, O. Isomaki, K. Pekkola-Heino, R. Merilahti-Palo, R. Saario, H. Isomaki, and A. Toivanen. 1989. Yersinia antigens in synovial-fluid cells from patients with reactive arthritis. $N$. Engl. J. Med. 320:216-221. 